\title{
The Execution of Final Judicial Decision as Part of Human Rights Legislation
}

\author{
Valentina Memini, PhD Candidate
}

\author{
The European University of Tirana \\ Faculty of Law \\ vmemini@uet.edu.al
}

\section{Doi:10.5901/ajis.2013.v2n8p333}

\begin{abstract}
The compulsory execution of judicial decisions like that of executive titles is one of the fundamental human rights and it serves to guarantee a regular procedure. Therefore, the decision of an independent and impartial court is meaningless in the case when no execution of a final judgment has taken place. The execution of the final judgment is an intrinsic element of the right for a regular legal process, in the framework of the article 42 of the Constitution and article 6 of the European Convention on Human Rights. The European Court of Human Rights has reached to the conclusion that if any of the parties refuses to abide by a final judgment, then the process has not finished yet, because when a party has won a case, but the decision is not executed, then his/her right are infringed. Based on the Constitutional Court, it could be derived that the execution of the final judgment is the last phase of a judicial process. Only upon the execution of such judgment one could say that the individual has won the case. A fair trial does not consist only to the process of court's decision-taking, but to the concrete actions taken by the bodies in charge to execute the final judgment. The process of the execution of the final judgment lacks with regard to the compliance with legal procedures, which is an indicator that human rights are broken. Reason to the lack of such compliance could be found to the debtor's lack of cooperation, indifference of state institutions, lack of a complete procedural legislation, lack of knowledge of the law from those in charge of the judicial decision execution, lack of funds which is especially evident in the case of the execution of the Law for the Return and Compensation of Properties and in the inability to afford the penalties placed by the European Court of Human Rights.
\end{abstract}

Keywords: human rights, final judicial decision, procedural legislation, regular legal process, executive titles.

\section{Introduction}

In the state of right, one of the essential principles of the democratic society, that focuses particularly on the respect of human rights, contains in itself even the duty of public authorities to execute the irrevocable judicial decisions, where their complete and effective implementation is of primary importance, with the purpose of establishing, consolidating, and developing of a judicial system that will be respectable by everyone. The execution of the irrevocable decisions is an important element of right for a regular and legal process, according to the article 42 of the Constitution and the Article 6 of the European Convention of Human Rights (Convention below), and is therefore a major part of Human Rights. The judgement should not be narrowly perceived, simply as a legal verdict but as the termination of the whole process, because a right gained is worthless if it is not achieved through the execution of the verdict.

The execution of the irrevocable verdict of the Court of Law is considered as the final stage of the realization of a right gained legally. Only after the realisation of this stage can the individual claim that he/she has accomplished his/her purpose about the gained right. Regarding what is mentioned above, in this stage must participate not only the parties, so the creditor and the debtor but also the competent institutions in charge of the execution of the irrevocable verdict, private or state owned bailiff offices. The role of the bailiff is determinative when the debtor refuses to willingly execute the duty towards the creditor. In such cases the process of correcting what was done to a disrespected right includes not only the proces of decision-making by the courts of law but the concrete actions of the responsible institutions which are in charge of executing the irrevocable judicial verdicts.

The Constitutional Court (the Court below) regarding the orientations given by the European Court of Human Rights (it will be found below as ECtHR) has declared that an issue that involves the specification of a civil right, the duration of the procedures is normally calculated from the moment when the legal procedure starts until the moment when the verdict is given and executed, in which the executive stage will be considered as the next phase of the same process. The reasonable duration of the procedures according to the article 42 of the Constitution, must be evaluated by taking in consideration the circumstances and the complexity of the case, the attitude and the interest of the seeker as 
well as the attitude of the specific authorities. The Court of Law has also emphasized that regarding the execution of the judiciary decisions that assign monetary duties towards the state, the person toward whom the state is a debtor, must not be asked to initiate procedures for the execution of the verdict in order to have the compensation for the decided amount. In such cases, the right state authority must be notified in the appropriate way for the verdict in order to be in the right conditions to take all the necessary precautions to fulfill its duty or to deliver it to another state authority that is competent for the execution.

The respect towards the basic human rights and liberties in Albania has been ans continues to be the main aim of the mission of the Albanian Helsinki Commitee (AHC) during the 22 years of its activity. Based on this activity, AHC has created the tradition of of compiling of an annual report about the respect of the human rights in the country as well as the problematic issues in this aspect. (http://.ahc.org.al/site/doc The report of the human rights, Legal Clinic, December 19, 2012 pdf).

Regarding the continuous practice the EctHR has considered an integral part of the article 6/1 of the AHC the right to demand the execution of an irrevocable verdict within a reasonable deadline. (See the decision of CHR Hornsby against Greece, March 19 1997; Georgiadis against Greece, March 28-th, 2000). ECTHR has continuously declared that the seeker must not be deprived to the right of benefiting from the favourable result of the legal process simply by supporting the argument of the financial inability of the state. (See the decision of CHR Hornsby against Greece, March 19 1997; Georgiadis against Greece, March 28-th, 2000). This Court of Law has underlined that the state must continously take responnsibility to sicure the parties involved in the process that they will have real opportunities to execute the irrevocable verdict and that the right to access the Court of Law would be an illusion if the judicial system or its practical execution would be the cause that an irrevocable verdict would remain ineffective and impossible to be executed for a very long time. As it is emphasized even in other well-known international documents, the complete implementation in the most effective and efficient way of the judiciary decisions is of primary importance for the states in order to establish, inforce, and develop a respectable by all judiciary system" . (The Resolution of the Conference of the European Ministers of Justice, October 4-5-th 2001). The state of right, as one of the basic principles of a democratic society, contains in itself the obligation of the public authorities to implement the orders or the irrevocable judicial verdicts. ( Decision of the ECTHR Hasan and Chaus against Bulgaria, No.30985/96, pg 87)

\section{The Execution of the Verdict as an Essential Element of the State of the Right}

The execution of the verdict is an essential element of the state of right and of the nocion of judging one right. No state organ can cast doubt on the righteousness of the irrevocable judiciary verdicts. Each state organ is obliged to take all the precautions in anticipation for their implementation. The execution of the irrevocable verdict of the court of law is considered as the final stage in the realization of a right gained legally. Only after the termination of this stage it can be considered that the individual has completely set the things to right. Therefore the procces of setting to right of a disregarded and disrespected right includes not only the process of decision making by the courts, but also the concrete actions of the organs in charge of the execution of the irrevocable judiciary verdicts. In general, the right of judgement within a reasonable period of time is an almost universal and constitutional standard and consiquently, the people who claim that they were affected by the lack of respect towards such a standard, as a rule, do not have legal obstacles to demand a constitutional judgement from the Constitutional Court, therefore it is known the right to bring a constitutional suit. (Sadushi,2012, p.100).

In order to make a complete analyses of the right of the parties based on the constitutional standards in the cases that are the object of investigation, introduced in the Constitutional Court under the objective of destroying the normal legal proces, (The Constitution of the Republic of Albania, 2010, article 131/f, The Constitutional Court decides that: the final judgment of the complaints of the individuals regarding the disrespect of their constitutional rights for a fair legal process, after the use of all the other juridical means for the defense of these rights), this Court takes into the consideration and analyses the provisions of the Code of Civil Procedure (CCP) related to the implementation of the judiciary decisions. These provisions clarify the legal procedures, which must be accomplished for the execution of a judiciary decision. Article 451/a of CCP provide that the decision which is irreversible must be obligatory for the parties, their predecessors, for the people that willingly withdraw from their right, for the court that announces the verdict as well as for all the courts and other institutions. Part 4 and more precisely article510 of CCP provide that the obligatory execution can be achieved only on the basis of an executive title where among others, the civil decisions of the court that are now irrevocable, consist executive title. Article 511 provides that the executive title is executed due to the demand of the creditor and on that purpose the order of the execution is made by the court based on the article 511 of CCP. The 
order of the execution is executed from the judiciary bailiiff always based on the request of the creditor, article 515 (The Code of Legal procedure of the Republic of Albania, 2010)

\section{The Irrevocable Judicial Verdict as an Executive Title}

Every individual, to realize his/her rights that have been violated by the subjects of right such as an individual or judiciary person has the right to return things in the previous state by addressing the court, which on its part will announce an irrevocable verdict.

The execution of the irrevocable verdicts is not only a reflection of the respect of legal order, but also of lots of elements that are elaborated bu the Constitutional Court for a case after case analysis after the conclusion related to the violation or not of the right because of the prolonged period of non execution (Zaganjori, 2011). The recognition of the Right by the courts is not enough in itself to restate a right, therefore the necessity arises that the other state organ defined by the law and with the right power to achieve its purpose (Lamani, 1962), the state or private bailiff services. Beside the European Court of the Human Rights there are 58 declared requests against Albania and 50 others that are about to be declared, in which it is claimed the violation of the rights of property as well as other rights related to it. In most of the cases the claims about the right of property according to article 1, Protokol 1, of the european Convention of the Human Rights are accompanied by the claims for the right of a fair legal process according to the article 6 and the right for effective means of complaint according to the article 13 of the ECHR. During 2000-2012 are stated verdicts for 20 cases of this kind against Albania, from which in 16 cases are observed violation of rights, sanctioned with the value of $6,571,876$ euros and $1.650 \mathrm{~m} 2$ land surface. Albania has completely executed 11 verdicts, has 2 verdicts in the execution process and three others in the process of negotiation for the value of award damages. (http://dsdc.gov.al "Intersectional strategies, reforms in the area of the right of property 2012-2020". The rights coincide with the start of 2012)

Albania has a clear legal obligation according to the article 46 of the ECHR to undertake the right precautions in order to execute the inner irrevocable decisions for the return and compensation as well as for the realization of an effective complaint in case of non- execution of the verdicts. The execution of the existent irrevocable verdicts is not only a special issue but also the most urgent from the perspective of the execution of certain verdicts of the European Court. In such situations the state has a wider evaluation margin to select the measures as well as its implementation. The Cometee of the Ministers of the EK has approved the 2010 Memorandum for the supervision of the execution of the verdicts of ECTHR by paying special attention to the cases of return and compensation of the property. In this document are verified the problems that require solutions based on the experience of the other states already members of the European Council. In answer to this document, the Council of Ministers has approved a DCM nr.350, date 29.04.201, (DCM no350, date 29.01.2011 "About the approval of the actions taken for the solution of the problems concerning the issue of property"), specified in the memorandum of the European Commitee of the Council of Ministers that includes the raport and the action plan about the ommiting of the obstacles for the implementation of the inner action that recognize, return and compesate property as well as the security of the effective means for the complaint in cases in which they are not respected. Of a great importance in relation to this problem is even the Decision of The Council of Ministers no.405, date 27.6.2012 "About the Approval of the intersectorial Strategy "The Reform in the area of the right of property, 20122020" and of its action plan. (http://.qbz.gov.al/edition/ legal papers/2012/PDF-2012/86-2012.pdf).

Among the strategic objectives related to the consolidation of the democratic state based on the basic rights and liberties of the individuals about the improvement of the execution of the judiciary verdicts, the Council of the Ministers has compiled and approved the draft-constitution "About the specification of the detailed analysis of the regulation for the occurrence of the auction " and has also drafted the draft-constitution "About the specification of the execution of the monetary duty of the state institutions for the sake of the public treasury". (Instruction no.2, date 18.08.2011. The council of Ministers "About the way of the execution of the monetary duties of the state institutions for the account of public treasury". This initiative has intended the execution of the judiciary verdicts in which the state is debtor.)

\section{The Practice of the Constitutional Court}

The Constitutional Court has a diverse practice regarding non-execution of judicial decisions in the light of respect for one of the basic rights - to a fair hearing.

1. In Decision no. 42, dated 19.07.2012, the Constitutional Court (here in after Court) has found a violation of due process as a result of failure to enforce the final court within a reasonable time. Pursuant to Article 142/3 of the Constitution, the state authorities are obliged to judicial decisions and it is self-executing provision of these 
bodies. State authorities can not avoid fulfilling this constitutional obligation directly with the claim that the execution of the court decision is rendered impossible or / and delayed simply and only because of the acts of others in the hierarchy of normative acts, sanctioned Article 116 of the Constitution, follow the Constitution because such a thing would lead to violation of the constitutional principle of the rule of law, the separation and balance of powers and the constitutional right to a fair trial. (The decision no. 42, date 19.07.2012, of the Constitutional Court). This decision consolidates the position held by the Court on violation of due process as a result of non-enforcement of a final court judgment within a reasonable time, but explaining the rules established by-laws do not preclude the obligation to avoid execution of constitutional court decisions. (Decisions: no. 8, date 23.3.2010; no. 13, date 22.4.2011; no. 13, date 21.03.2012 of the Constitutional Court).

2. In Decision no. 49, dated 26.07.2012, the Constitutional Court found a violation of the constitutional right to a fair hearing, as a result of the failure to enforce a final court of Tirana District Court in 2010. Execution, within a reasonable time, a final decision of the court, should be considered as an integral part of the right to a fair hearing. It is the final stage of implementation of the right to earn a judicially. A delay in execution of a judgment may be justified in certain circumstances, but there can be delays to such an extent as to impair the essence of the right. Reasonable length of proceedings must be assessed under the circumstances of the case and taking into account the complexity of the case, the conduct of the applicant and the relevant authorities and the applicant's interest. The issue is not specific to particular circumstances or complexity of the factual or legal point of view, that could justify a delay in the execution of the decision, to assess the behavior of public authorities and researchers is important in this context. The applicant, during the plenary session, specified that has renounced his return to work, for this reason the Court has taken in his analysis of the claims relating to the payment of salary. State authorities can not cite lack of funds as an excuse for not honoring a financial obligation arising from a judicial decision. Although METE (The Ministry of Economy, Trade and Energetics), has shown willingness to fulfill the obligation to the creditor by ordering the payment of a part thereof, the Court considers that the amount of unilaterally defined in quota of 10,000 leks per month starting from August 2011 to December 2012, for a total of 180,000 lek is disproportionate, unreasonable and unjustified in relation to the full extent of the value of the obligation in favor of the applicant (from 5,833,952 ALL), which itself violates the essence of this right and reasonable to delay the execution (The decision no. 48, date 26.07.2012, of the Constitutional Court). In this decision the Constitutional Court consolidated the position with regard to the assessment of delays in execution of a judicial decision, as a very important aspect of due process.

3. Similarly, in decision no. 49 , dated 26.07 .2012 , the Constitutional Court found a violation of the constitutional right to a fair hearing, due to the failure to enforce a final court decision of Korca's District Court in 1996. The issue under scrutiny does not manifest any factual or legal complexity. The applicant cannot be held liable because, due to various reasons, s/he requested the suspension of the execution procedure of this decision for a two-year period 2009-2011. As ECTHR states, a person who receives an enforceable decision against the state in his favour, cannot be asked to go to enforcement bodies for the execution of the court decision. In terms of public authorities, getting aware of the financial liability stemming from the verdict final, Korca Municipality debtor should take all necessary measures for its execution and should not expect the propulsion of enforcement procedures, to restrictive measures (see the decision of the ECHR, dated 22.08.2006, in case Basheer and others v. Albania). While actions have been formally Executive Office, she did not use all legal means available, also in reference to Article 589 of the CPC, which recognizes the right of this subject, as is the case, he asks himself the superior release of funds for the purpose of execution of duties, and can apply sanctions against those responsible for the failure. (Decision no. 49, date 26.07.2012,The constitutional Court.)

\section{Conclusions/ Recommendation}

The execution of a final decision of the court is considered as the final stage of implementation of the right earned judicially. Only after completion of this phase can be considered that the individual has fully set in place the legal right. At this stage should not only actively participating parties, debtor and creditor, but the authorities charged with the enforcement of final judicial, executive offices, public or private. The role of the enforcement body becomes crucial when the debtor refuses to voluntarily execute his obligation towards the creditor. Therefore, in such cases it can be said that the process of setting in place of a right includes not only the violated court decisions, but the concrete actions of the 
responsible bodies charged with the execution of judicial decisions.

In a case involving the determination of a civil right, the length of proceedings is normally calculated from the start of the proceedings, until the decision is given and executed, where executive phases will be considered as a further stage of the same process. Execution of the decision constitutes an essential element of the rule of law and the very idea of a fair trial. No state organ can be put into question about the fairness of final judicial decisions. Any public body is obliged to take appropriate measures for their implementation, and can not cite lack of funds as an excuse for not honoring a financial obligation arising from a judicial decision.

In terms of public authority, getting aware of the financial liability that results from an irrevocable verdict, the debtor that may be a state institution must take all necessary measures for its execution and must not wait for the execution of procedures until the obligatory measures are put into practice in a way that the creditor can realize its right.

References

Constitution of the Republic of Albania, Alb Juris, Tirana, 2010;

Code of Civil Procedure of the Republic of Albania, edition of the Official Publications Centre, Tirana, 2010;

Instruction no. 2, dated 18.08.2011, Kshilli of Ministers "On the execution of monetary liabilities budgetary institutions treasury account"; DCM. 350, dated 29.04.2011 "On approval of the action plan for solving the problems of ownership issues";

The decision of the ECHR, Hornsby v. Greece, March 19, 1997;

The decision of the ECHR, Georgiadis v. Greece, March 28, 2000;

The decision of the ECHR, Burdov against Russia, Nr.59498, 2002;

The decision of the ECHR, Shilyayev against Russia, Nr.9647/02, 6 October 2005;

Hasan ECHR decision against Bulgaria and Chaus, no. 30985/96

Decision no. 42, dated 19.07.2012, the Constitutional Court;

Decision no. 48, dated 26.07.2012, the Constitutional Court;

Decision no. 49, dated 26.07.2012, the Constitutional Court;

Decision no. 8, dated 23.03.2010, the Constitutional Court;

Decision no. 13, dated 22.4.2011, the Constitutional Court;

Decision no. 13, dated 21.03.2012, the Constitutional Court;

J. Zaganjori., A. Anastasi, E. Cani, Sheteti of law in the Constitution of the Republic of Albania Adel, Tirana, 2011;

Sadushi S., Constitutional Justice in Development, Toena, Tirana, 2012;

Laman A. Civil Procedure of the People's Republic of Albania, Tirana, 1962;

Resolution of the Conference of European Ministers of Justice, 4 to 5 October 2001;

http://.dsdc.gov.al, "crosscutting strategy, reforms in the area of property rights 2012-2020"; 